\title{
Limited Take-up of Ecocertification by Tourism Firms: a Goldilocks Effect?
}

\begin{abstract}
Mzembe et al. (2020) used club theory to examine why tourism operators adopt or abandon ecocertification. In this Opinion, I apply their results to the principal type of tourism ecocertification, namely private third-party programs funded by membership fees. I argue that club theory can resolve a longstanding paradox for these programs: despite low take-up amongst potential members, they continue to persist. I propose that this paradox can be analysed as a Goldilocks effect. Programs start by signing up high-performing enterprises, creating an attractive club. To sign up more new members, however, they then lower entry standards, opening membership to poorly performing enterprises. This makes the certification club less exclusive, and dilutes benefits. In addition, if only few tourist clients rely on ecocertificates, it creates intra-club rivalry for benefits. This makes club membership less attractive to the early-joining, high-performing members, which then leave, creating member turnover and keeping overall take-up low. To be of value, theoretical analyses of tourism must be able to represent and replicate observed realities in the tourism industry. Where they do not, theories must evolve accordingly. The adoption of club theory by Mzembe et al. (2020) to analyse ecocertification can resolve one such previously unexplained paradox.
\end{abstract}

Keywords: club theory; ecolabel; quality; marketing; rivalry; exclusivity

\section{Introduction: Applying Club Theory.}

Club theory provides valuable insights into tourism ecocertification (Mzembe et al., 2020). Here, I re-examine one of their conclusions, in the light of previous research in this field. I consider whether their results support the existence of a "Goldilocks effect" in the take-up of tourism ecocertification programs, by tourism enterprises. My focus here is on take-up of individual programs, not proliferation of different programs.

From a theoretical perspective, a club is defined by three concurrent criteria. First, members must apply, and pay or compete, to join the club. Second, club members enjoy definable benefits, from which non-members are excluded. Third, those benefits are available equally to all members, and non-rival between members. As identified by Mzembe et al. (2020), these do indeed apply, at least notionally, to tourism ecocertification programs.

The specific aspect addressed here, is whether the club structure determines the degree of penetration for these programs, into the potential target market. I examine whether the proportion of tourism firms joining ecocertification programs may be subject to a Goldilocks effect, a term drawn from the (Western) fable of Goldilocks and the Three Bears. The term is now used in many academic disciplines (Lawson, 2001), to describe parameters that are confined within a central range by two opposing effects, or are observable only because they fall within such a range.

Tourism ecocertification is one form of tourism ecolabel, itself one form of tourism quality label (Font, 2002; Lesar et al., 2020). Quality labels and certificates, including environmental versions, also exist in other industry sectors, and across multiple sectors simultaneously. Third-party programs may be run either by government agencies, non-government organizations, or industry associations (Lesar et al. 2020). The Goldilocks argument may apply to greater or lesser degree to non-tourism industry sectors, and non-eco forms of 
quality label. It may not apply to government-run or government-endorsed programs, where certification providers are generally not dependent on marketing to potential members in order to remain operational. Here, I consider only how it may apply for privately-run, thirdparty, tourism ecocertification programs.

\section{Take-up of Tourism Ecocertification}

Take-up of tourism ecocertification programs may be measured from either tourist or tourism-firm perspectives. The former measures the proportion of tourists who modify purchase decisions based on ecocertificates. The latter, which is the aspect considered here, measures the proportion of potentially certifiable enterprises that have adopted or applied for certification, and have not relinquished it.

There are many quality labels, in tourism and other sectors, where take-up is high. For many tourism ecocertification programs, however, take-up has neither grown so large that it encompasses the majority of eligible enterprises, nor fallen so low that the programs collapse. It has remained at moderate levels, for several decades. Using the findings of Mzembe et al. (2020), I argue here that when new programs commence operations, there are pressures for firms to join up; but as they expand, there are counter-pressures for firms to drop out.

High take-up is not in itself essential to a successful club. Some of the best-known and most highly-coveted club memberships are extremely restricted. In tourism quality certification, for example, luxury labels such as Relais et Chateaux, and Small Luxury Hotels of the World, remain highly successful. Their small membership numbers, however, are due to strict and highly competitive entry standards, not lack of demand amongst enterprises. These labels allow members to charge substantial price premiums, and certification programs to charge substantial annual fees. For tourism ecocertification programs, however, price premiums are considerably smaller, so they can only support smaller membership fees. Therefore, take-up is more critical to survival of these schemes.

\section{Why Join Up? Market Access, Price Premium}

There are several reasons why individual tourism enterprises may apply for ecocertification. The first is through personal concerns of staff or local management. Ecocertification, however, does not in itself address such issues. The second is through unavoidable external instructions: e.g., as a legal operating requirement, or from a higher level in the company (Mzembe et al., 2020). The third is to cut costs, eg by reducing consumption of power and water. Cost savings through efficiency, however, can be achieved without certification. In addition, some tourism enterprises are driven to efficiency externally, e.g. through locations remote from public utilities, and apply for ecocertification as a secondary consideration.

The fourth and principal reason is to improve revenue. There are two main subsidiary mechanisms. The first is that ecocertification could increase sales or yield a price premium: either from a small market subsector strongly concerned about the environment, or from a larger sector for whom it is one of many considerations (Buckley and Mossaz, 2016, 2018). Such sales boosts and price premiums seem in practice to be small. The second revenueboosting mechanism is to gain access to specific markets. Some government agencies require certification, as a precondition for operating permits in particular areas, or to bid for government contracts. In some countries, companies need certification in order to gain a social license to operate: e.g., political support for proposed new ventures. This seems to be 
the more important of the revenue mechanisms (Mzembe et al., 2020), and overall, the principal member benefit of ecocertification programs.

\section{Costs and Benefits}

Ecocertification also involves costs. These include: costs of modifying operations to meet certification criteria; costs of collecting data, completing paperwork, and complying with administrative requirements; application, annual and audit fees to the certification program; and at least potentially, reductions in revenue, if compliance with certification requirements reduces the level of luxury offered to guests. This last option may also be confounded with a separate pattern, under which premises in less favourable areas, or with fewer attractions or lower levels of luxury, may preferentially market eco credentials.

From the club theory perspective adopted by Mzembe et al. (2020), these costs represent the payment to join the club; and the increased revenue represents the benefits of membership. For certification to generate net value, the net benefits must be positive; and in addition, the benefits should be excludable and non-rival: i.e., available only to club members, and not competitive between club members (Mzembe et al., 2020).

I argue here, using the club theory advanced by Mzembe et al. (2020), that tourism enterprises will quit ecocertification programs if: (a) net benefits decrease to zero; (b) members compete for benefits, in a fixed-sum game; \&/or (c) members cannot exclude nonmembers from acquiring the same benefits. I also argue that all of these mechanisms do indeed operate, because of (a) the business model adopted by third-party tourism ecocertification providers; (b) patterns of environmental concern and purchasing amongst tourists; and (c) alternative mechanisms available to tourism enterprises, to gain benefits without ecocertification.

\section{Third-Party Certifier Business Models}

From the perspective of private third-party ecocertification providers, their business model depends on fees from members. To survive and prosper, they need to recruit and retain members, and increase yields by raising prices and charging for additional services. For example, they add destination as well as enterprise ecocertification categories, because they can charge destinations much higher fees. Their ability to recruit and retain members depends on member and potential-member perceptions of net benefits, non-rivalry, and excludability.

Therefore, for example, tourism ecocertification programs negotiate actively with industry associations and government agencies, to gain preferences for their certified members at the expense of uncertified non-members: i.e., to provide preferential market access. They provide members with marketing collateral, such as ecocertification tags and logos. And to a limited degree, they also market their ecocertification programs directly to individual tourists. These actions create an initial pressure for increased take-up of ecocertification programs: i.e., adding more members to the club. When membership numbers are small, existing members all gain when new members join, because that increases visibility and potential reliance on the program by both clients and regulators.

\section{Recruitment, Retention, and Relaxation of Standards}


The principal recruitment strategy adopted by tourism ecocertification programs, however, is to lower barriers to club entry. Some allow enterprises to join up without meeting any technical criteria, simply by promising to improve environmental management in future. Some offer multiple membership tiers, with lax criteria for entry-level tiers, and more meaningful criteria only for higher tiers. Therefore, enterprises with poor environmental management may still gain membership (Mzembe et al., 2020).

In addition, many programs have weak monitoring, audit and enforcement of compliance, so that poorly performing tourism firms can still retain membership (Mzembe et al., 2020). Later members may free-ride on brand reputation established by high-performing early members. They may shirk compliance, by meeting standards only on audit days, or by continuing to use the logo even after failing to re-apply or re-qualify (Mzembe et al., 2020). This decreases perceived reliability and reputation, and hence revenue, for high as well as low-performing firms. Commercial pressure for recruitment and retention of members thus leads to lax standards, which reduce the net benefits of membership. If standards are relaxed, eg through failure of audits or through addition of lower tiers, membership loses its value for early adopters, who met high-tier standards.

\section{Rivalry and Non-Excludability}

If few potential purchasers are influenced by ecocertificates, and enterprises compete for these clients, then the benefits of club membership are no longer non-rival. If so, adding members dilutes individual benefits, until they no longer outweigh costs. This does indeed seem to be the pattern, with few purchasing decisions driven strongly by environmental considerations, even in the strongly pro-environment conservation tourism subsector (Buckley \& Mossaz, 2016, 2018). Most tourists expect tourism firms to comply with environmental laws, but do not expect to pay extra for them to do so (Mair and Jago, 2010).

Ecocertification programs may also be unable to exclude non-members from benefits, if similar benefits can be obtained without certification. Many companies market their own environmental management programs directly, either as superior to existing ecocertification programs, or in imitation of them. In other industries, some companies market labels that are merely in-house logos; and others have imitated government labels, but with no underpinning standards. Tourists do not discriminate clearly between ecolabels, or between tiers in the same ecolabel (Sparks et al., 2018). If tourism enterprises can achieve the same marketing benefits as those provided by membership of an ecocertification club, but without incurring costs of compliance or fees, then joining the club becomes worthless.

\section{Goldilocks Outcomes and Certification Structures}

When tourism ecocertification programs have few members, as in the low-uptake initial phases, then net benefits to members are positive, non-rival, and excludable. This is the first part of the Goldilocks couplet, driving increased take-up. Once take-up increases, however, benefits are reduced, diluted, rival, and non-excludable. This creates the second component of the Goldilocks couplet, pressure for declining membership. Once departures equal or exceed recruitment, membership numbers stabilize, at low or moderate levels.

This Goldilocks mechanism applies only for private third-party certification programs reliant on membership fees. That is, it is a feature of club systems specifically, which is why the club theory approach of Mzembe et al. (2020) proves so revealing. It does not apply to 
quality labels or certification systems that are operated by governments, such as food or pharmaceutical standards; or endorsed by governments via a mandatory monopoly private provider, such as professional licencing for doctors, lawyers, or engineers. Nor does it apply for systems that are operated externally without enterprises applying, such as Michelin stars for restaurants, or automobile-club ratings for roadside accommodation.

\section{Conclusions}

I argue here that the club-theory approach and findings of Mzembe et al. (2020), for one specific tourism ecocertification program, suggest a general mechanism for low take-up of ecocertification programs, by tourism enterprises at which they are aimed. This mechanism is a Goldilocks effect, where the approaches used by ecocertification programs to recruit and retain additional members, lower the benefits for existing members. There is thus a couplet of opposing pressures. When take-up is small, there is a pressure for it to grow; but when it is larger, there is a pressure for it to shrink. The responses provided by tourism firms interviewed by Mzembe et al. (2020) reveal exactly this effect.

This argument applies only to take-up by tourism enterprises, of individual ecocertification programs. It does not apply to proliferation of different programs. Nor does it apply directly to the adoption of ecocertificates by tourists, though this is connected via brand reputation. It may or may not apply to other forms of third-party quality label, in tourism and other sectors. It does not necessarily apply to quality label programs that lack a club structure.

The Goldilocks argument could be tested further using two main approaches. The first, mentioned briefly above, would be to duplicate the approach of Mzembe et al. (2020), but with government-funded programs that are not dependent on recruitment for membership fees. Alternatively, we could interview members of private third-party programs that crosssubsidise ecocertification from other sources of funds.

The second approach would be to focus on rivalry and excludability of membership benefits. These have not been analysed for tourism ecocertification, because until the club theory approach of Mzembe et al. (2020), they were not recognised as key components. It would now be possible to interview managers and marketers of ecocertified tourism firms, asking if they find themselves in competition for the same limited market of eco-conscious clients. It would also be feasible to test whether individual tourists distinguish between reliable and unreliable ecocertificates, third party $c f$. first party, multi-tier $c f$. single-tier, promised improvement $v s$. current performance.

\section{References}

Mzembe, A.N., Lindgreen, A., Idemudia, U., \& Melissen, F. (2020). A club perspective on sustainability certification schemes in the tourism and hospitality industry. Journal of Sustainable Tourism, 28, 1332-1350.

Buckley, R., \& Mossaz, A. C. (2016). Decision making by specialist luxury travel agents. Tourism Management, 55, 133-138.

Buckley, R., \& Mossaz, A. (2018). Private conservation funding from wildlife tourism enterprises in sub-Saharan Africa: Conservation marketing beliefs and practices. Biological Conservation, 218, 57-63. 
Font, X. (2002). Environmental certification in tourism and hospitality: progress, process and prospects. Tourism Management, 23, 197-205.

Lawton, J. 2001. Earth system science. Science, 292, 1965.

Lesar, L., Weaver, D., \& Gardiner, S. (2019). From spectrum to multiverse: a new perspective on the diversity of quality control tools for sustainable tourism theory and practice. Journal of Travel Research, doi: 10.1177/0047287519841715.

Mair, J., \& Jago, L. (2010). The development of a conceptual model of greening in the business events tourism sector. Journal of Sustainable Tourism, 18, 77-94.

Sparks, B.A., Perkins, H.E., \& Buckley, R.C. (2013). Online travel reviews as persuasive communication: the effects of content type, source, and certification logos on consumer behaviour. Tourism Management, 39, 1-9. 